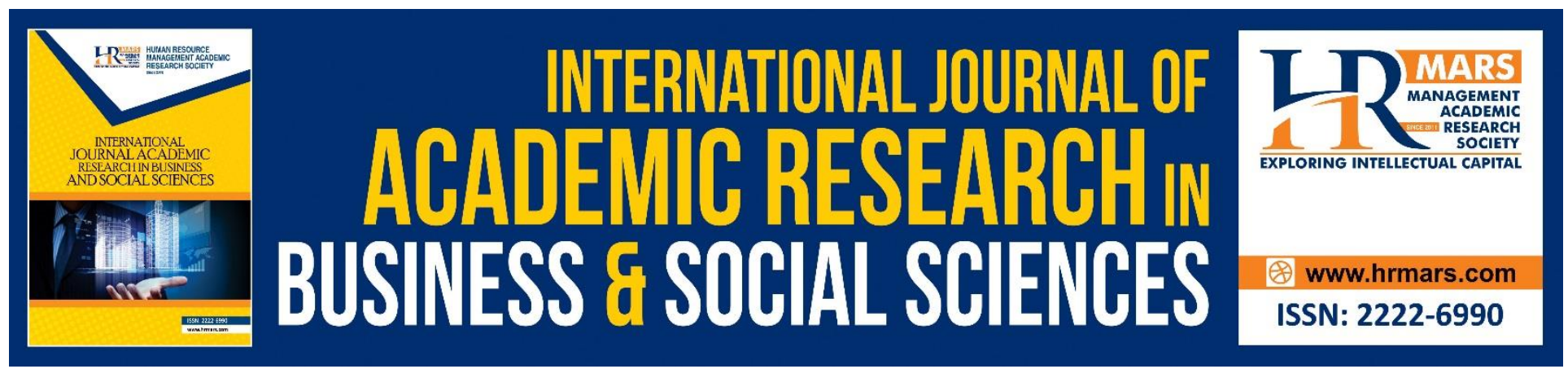

\title{
Sufficiency of Donation Received Among Private Islamic School in Malaysia: Does Reputation Matters?
}

\author{
Azira Hanani Ab Rahman, Sofri Yahya
}

To Link this Article: http://dx.doi.org/10.6007/IJARBSS/v10-i9/7871

DOI:10.6007/IJARBSS/v10-i9/7871

Received: 15 June 2020, Revised: 17 July 2020, Accepted: 19 August 2020

Published Online: 22 September 2020

In-Text Citation: (Ab Rahman, \& Yahya, 2020)

To Cite this Article: Ab Rahman, A. H., \& Yahya, S. (2020). Sufficiency of Donation Received Among Private Islamic School in Malaysia: Does Reputation Matters? International Journal of Academic Research in Business and Social Sciences. 10(9), 839-847.

Copyright: (C) 2020 The Author(s)

Published by Human Resource Management Academic Research Society (www.hrmars.com)

This article is published under the Creative Commons Attribution (CC BY 4.0) license. Anyone may reproduce, distribute, translate and create derivative works of this article (for both commercial and non-commercial purposes), subject to full attribution to the original publication and authors. The full terms of this license may be seen

at: http://creativecommons.org/licences/by/4.0/legalcode

Vol. 10, No. 9, 2020, Pg. 839 - 847

http://hrmars.com/index.php/pages/detail/IJARBSS

JOURNAL HOMEPAGE

Full Terms \& Conditions of access and use can be found at http://hrmars.com/index.php/pages/detail/publication-ethics 


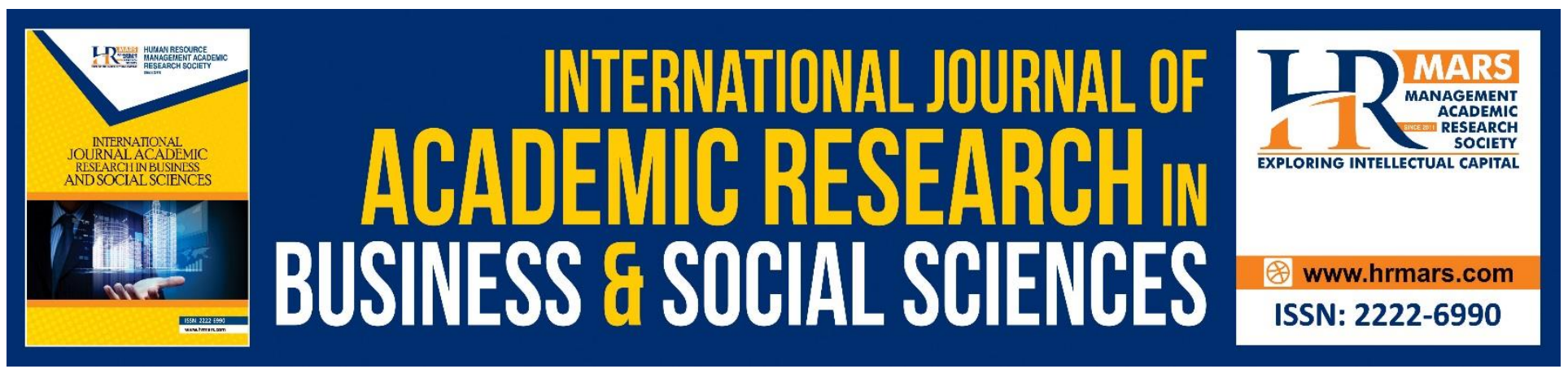

\title{
Sufficiency of Donation Received Among Private Islamic School in Malaysia: Does Reputation Matters?
}

\author{
Azira Hanani Ab Rahman, Sofri Yahya \\ Graduate School of Business, Jalan Ilmu, Universiti Sains Malaysia, 11800 Pulau Pinang, Malaysia
}

\begin{abstract}
Sufficient financial resources are important to ensure non-profit organisations can achieve the defined goals and objectives as well as to ensure that the organization remains competitive and relevant. Private Islamic schools are non-profit organizations founded by individuals, nongovernmental organizations or Islamic organizations to meet the Muslim society's need for a balanced academic and religious education. However, most private Islamic schools in Malaysia are facing with financial difficulties that prevent them from carrying out activities and development as planned. The main financial resource for these private Islamic religious schools is student fees, but the fees alone are insufficient to cover the overall cost of planned operations and development. As such, private Islamic religious schools in Malaysia rely heavily on donation from individuals and corporate bodies. Using a cross sectional survey design, this study intended to explore the relationship of reputation to the sufficiency of donation received by private Islamic schools in Malaysia. The Smartpls (v. 3.2.9) software was used to run the Structural Equation Modelling (SEM) technique and the findings showed that the sufficiency of donation received by private Islamic schools in Malaysia is influenced by a good reputation. It is hoped that future studies focus on separate studies involving pondok institution, tahfiz schools as well as SRI and SMI to obtain more comprehensive results.
\end{abstract}

Keywords: Reputation, Non-Profit Organisations, Private Islamic Schools, Sufficiency of Donation, Smart PLS.

\section{Introduction}

It is common for non-profit organisations to receive contributions from the general public, corporations or other stakeholders. The donations from various stakeholders are an important source of funding since these organisations depend on it to run their organisations and carry out their responsibilities (Banding \& Mayangsari, 2017; Donkers et al., 2016; Kashif et al., 2015). Sufficient financial resources are important to ensure non-profit organisations can achieve the defined goals and objectives as well as to ensure that the organization remains competitive and relevant.

The sufficiency and the amount of donations received by private Islamic schools are closely related to the giving behaviour of donors and other stakeholders. In today's highly competitive and resource-scarce environment, non-profit organizations must create a positive image and reputation 
to gain the public's favour and trust and consequently, more donations, since the image and reputation of a non-profit organisation is critical in influencing a donor's behaviour (Huang \& $\mathrm{Ku}$, 2016). Finding from Sargeant (2001); Sargeant and Lee (2002) posit that donors tend to donate to organisations that portray good reputation in the eyes of stakeholders. These findings were also supported by Moraga, Parraga, and Barra, (2010). Donors prefer to repeat a donation and increase the amount of the donation if donors believe that the organisation has a good reputation. Kong and Farrell (2010) also argued that reputation is a dominant element that supports non-profit organisations in developing and managing relationships with external stakeholders. The study added that this kind of relationship can assist organisations in gaining important resources, such as donations and volunteer support.

However, the growing number of negative issues faced by private Islamic schools in Malaysia, as reported in the local media, might have tarnished the reputation of these schools. This situation has raised public concern over the operation and existence of these schools (Andres, 2017; Aziz, 2018; Bernama, 2018; Ying, 2018). These negative issues and incidents not only tarnish the school's reputation, but it also discourages donors from donating to these school funds. Therefore, it is vital for these schools to establish a good reputation in order to be successful and ensure their existence in the market.

Among the biggest challenges faced by private Islamic schools in Malaysia is to maintain its financial sustainability in the long run (Shamsuri, 2018). Sustainable and sufficient financial income is vital for these schools to flourish, ensuring that physical development runs smoothly as planned, the welfare of teachers and other staff is guaranteed, creation of a conducive learning environment and so forth. However, as a non-profit organisation, most private Islamic schools in Malaysia have insufficient funds that denies them from further development as well as providing adequate facilities for their students since most of these schools are run by individuals, non-government organisations (NGOs) or Islamic Foundations that solely depend on students' fees as a major financial resource (Daud et al., 2012). Private Islamic schools in Malaysia are not solely profit orientered, but more importantly, they serve to provide Islamic education as an alternative to the national education system. Therefore, the tuition fees charged by these schools are relatively low compared to other private schools in Malaysia. In addition, some schools highly subsidise these tuition fees, and there are some schools that do not charge any fees to a certain category of students, such as orphans and students from very poor families.

Therefore, to establish a good reputation is the key concern of the private Islamic school's management is in order to attract more students to study at their institution as well as to gain the support of potential donors. Good reputation could pave the way for these private Islamic schools to be competitive in the market, which could then influence stakeholders to consistently contribute funds to these schools. Thus, this study attempts to unravel the issue by exploring the relationship between reputation and the sufficiency of donation received by private Islamic schools in Malaysia. The conceptual research model can be described as in Fig. 1 below: 


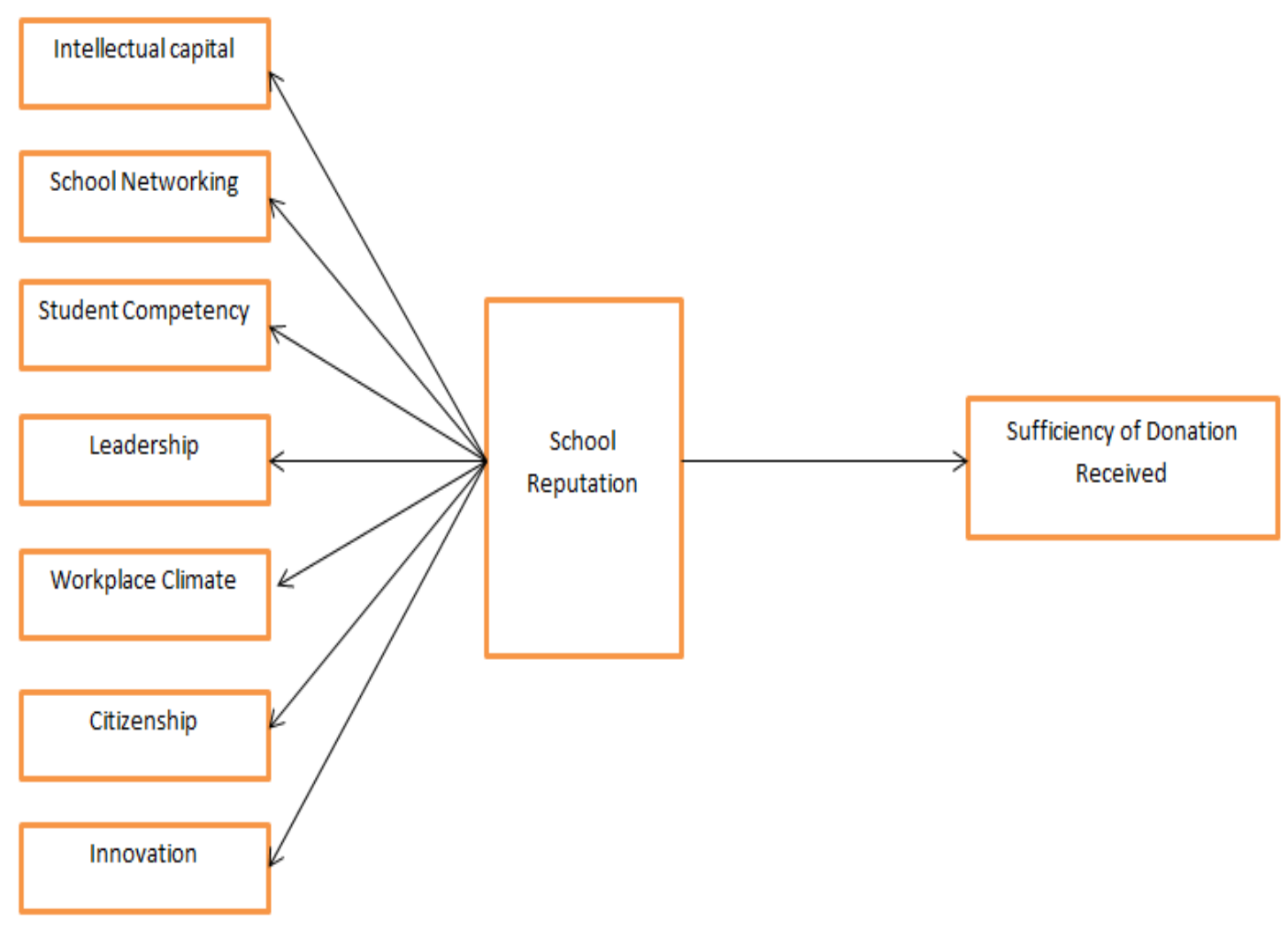

Figure 1: Conceptual Framework

The study consists of four parts. Firstly, this study discuss on the overview of reputation and its relation to sufficiency of donation received by private Islamic schools in Malaysia. Secondly the model and the methods used to investigate the relationships between these concepts will be described and explained. Thirdly, the results of the study are presented, analysed and discussed. Finally, a conclusion including managerial implications concerning reputation will be provided.

\section{Methodology}

\section{Population and Sample Size}

Presently, there are 1148 registered private Islamic schools listed by JAKIM. However, this study will only include private Islamic schools that have been established for more than five years since new organizations need time to establish themselves with donors and achieve recognition. List of the schools is obtained from JAKIM's portal as well as from the list provided by State Islamic Religious Councils (SIRC). Due to incomplete data provided by JAKIM and SIRC regarding the year of establishment, this study's population only comprised 345 schools. The complete number of private Islamic schools in Malaysia according to the numerous categories of schools is shown in Table 1. 
INTERNATIONAL JOURNAL OF ACADEMIC RESEARCH IN BUSINESS AND SOCIAL SCIENCES Vol. 10, No. 9, 2020, E-ISSN: 2222-6990 @ 2020 HRMARS

Table 1: Distribution of Population According to School Categories for 2019

\begin{tabular}{|c|c|c|c|c|c|}
\hline States & $\begin{array}{c}\text { Pondok/ } \\
\text { Madrasah }\end{array}$ & Tahfiz School & $\begin{array}{l}\text { Islamic } \\
\text { Primary }\end{array}$ & $\begin{array}{c}\text { Islamic } \\
\text { Secondary }\end{array}$ & Total \\
\hline Terengganu & 2 & 1 & 0 & 1 & 4 \\
\hline Perlis & 1 & 3 & 0 & 0 & 4 \\
\hline Pulau Pinang & 3 & 9 & 2 & 1 & 15 \\
\hline Kedah & 18 & 34 & 6 & 4 & 62 \\
\hline Melaka & 6 & 7 & 0 & 3 & 16 \\
\hline Neg Sembilan & 0 & 11 & 3 & 1 & 15 \\
\hline Johor & 5 & 19 & 6 & 5 & 35 \\
\hline Sabah & 0 & 0 & 0 & 0 & 0 \\
\hline Sarawak & 0 & 0 & 2 & 0 & 2 \\
\hline Wilayah Persekutuan & 0 & 1 & 1 & 1 & 3 \\
\hline
\end{tabular}

Sources: Department of Islamic Development Malaysia (JAKIM) and State Religious Councils

\section{Data Collection Method}

A total of 200 questionnaires were distributed to the respective private Islamic schools. In order to enhance the response rate and gather personal experience and observation, the questionnaires were delivered by the researcher and enumerators appointed by the researcher through personal visit. Phone calls were made before visiting the respective schools for seeking their permission and setting an appointment. Besides that, some questionnaires were also emailed to schools that have not been covered by personal visits. The schools were asked to complete the self-administered questionnaire in Google form and return the answer online.

Table 2: Distribution of Questionnaires to Respondents

\begin{tabular}{lccc}
\hline School Categories & $\begin{array}{c}\text { Number of } \\
\text { Schools }\end{array}$ & Percentage & $\begin{array}{c}\text { Total Questionnaire } \\
\text { Allocation (\% x 200) }\end{array}$ \\
\hline Pondok/ Madrasah & 61 & $18 \%$ & 36 \\
Tahfiz & 189 & $55 \%$ & 110 \\
Islamic Primary & 70 & $20 \%$ & 40 \\
Islamic Secondary & 25 & $\mathbf{7 \%}$ & 14 \\
\hline Total & $\mathbf{3 4 5}$ & $\mathbf{1 0 0 \%}$ & $\mathbf{2 0 0}$ \\
\hline
\end{tabular}

\section{Data Analysis}

This study used two statistical analysis techniques, which are the Statistic Package for Social Science (SPSS) and SmartPLS (PLS-SEM) version 3.2.9. SPSS were employed to analyse the sample's basic statistics. Meanwhile, the confirmatory factor analysis and hypothesis testing were performed using SmartLPS.

\section{Results of Findings and Discussion Response Rate}

A total of 200 questionnaires were distributed to the respective private Islamic schools. Out of 200 questionnaires, 148 were completed and returned, which is equivalent to a response rate of $74 \%$. However, two questionnaires were excluded because the respondents provided similar responses (straight lining) to all questions in the survey, resulting in 146 usable completed surveys (73\% usable response rate). Summary of the questionnaire's rate of return is shown in Table 3. 
INTERNATIONAL JOURNAL OF ACADEMIC RESEARCH IN BUSINESS AND SOCIAL SCIENCES Vol. 10, No. 9, 2020, E-ISSN: 2222-6990 @ 2020 HRMARS

Table 3: Response rate

\begin{tabular}{lcccc}
\hline $\begin{array}{c}\text { School } \\
\text { Category }\end{array}$ & $\begin{array}{c}\text { Number of } \\
\text { Schools }\end{array}$ & $\begin{array}{c}\text { Questionnaires } \\
\text { Distributed }\end{array}$ & $\begin{array}{c}\text { Response } \\
\text { Received }\end{array}$ & Valid \\
\hline Primary School & 70 & 40 & 31 & 31 \\
Secondary School & 25 & 14 & 9 & 9 \\
Tahfiz School & 189 & 110 & 85 & 83 \\
Pondok/Madrasah & 61 & 36 & 23 & 23 \\
\hline Total & $\mathbf{3 4 5}$ & $\mathbf{2 0 0}$ & $\mathbf{1 4 8}$ & $\mathbf{1 4 6}$ \\
\hline
\end{tabular}

\section{Descriptive Analysis}

The highest number of respondents was from Tahfiz schools, followed by primary schools, Pondok/ Madrasah and secondary schools. Majority of the schools were located in the Northern Region, however Selangor recorded the highest number of respondents. A majority of private Islamic schools involved in this study have contributed towards education service operations for between 5-10 years while 4 schools were established more than 50 years ago. In terms of the number of employees, most schools reported that they have between 2-20 employees. Majority of schools involved in this study had more than 100 students with the largest number of students recorded at 1,248. In terms of the fees charged to students, $4.8 \%$ of schools did not charge any fee or have no fixed charges. This means that students pay their fees based on their parent's affordability. Majority of the schools charge tuition fees from RM 151 - RM 250 per month.

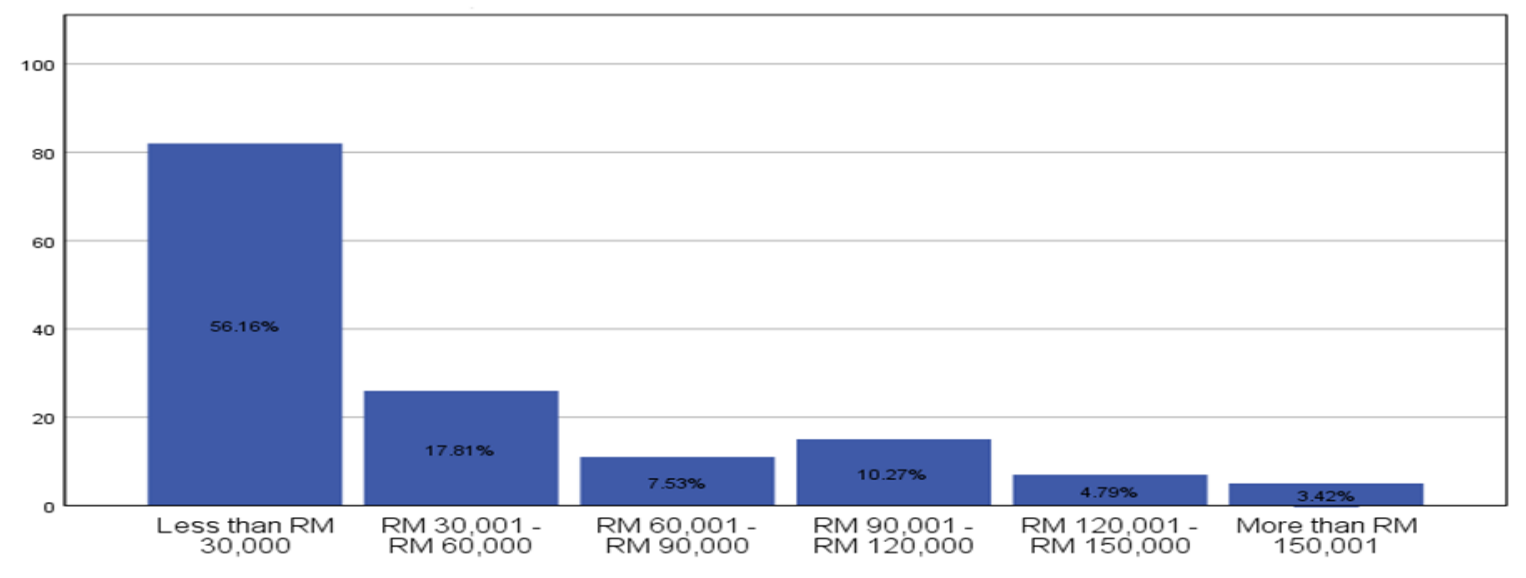

Figure 2: The Amount of Donation Received

The Figure 2 above shows the amount of donation received by responding schools. Based on the graph, it shows that majority of the schools received donation less than RM 30,000 a year and only 5 schools received more than RM 150,000 a year. Furthermore, 15.28\% of the respondents feel that the donation received are insufficient at all and $44.44 \%$ feel that the donation received is slightly sufficient.

\section{Convergent Validity}

Convergent validity refers to the extent of the positive correlation measurement with alternative measures of the same construct (Hair et al., 2014). To evaluate convergent validity of reflective constructs, studies consider the outer loadings of the indicators and the average variance extracted 
INTERNATIONAL JOURNAL OF ACADEMIC RESEARCH IN BUSINESS AND SOCIAL SCIENCES Vol. 10, No. 9, 2020, E-ISSN: 2222-6990 @ 2020 HRMARS

(AVE) (Hair et.al, 2017). A common rule of thumb is that the standardized outer loadings should be 0.708 or higher (Hair et al., 2017). However, according to Hair et al. (2014), items with moderate loadings between 0.5 to 0.7 can be retained as long as the Average Variance Extracted (AVE) for latent variables is above 0.5. Table 5 shows the results for convergent validity. In order to retain an AVE of above 0.50 , some items with weaker outer loadings (below 0.708 ) were removed.

Table 4: Results of Convergent Validity

\begin{tabular}{ccccc}
\hline Construct & $\begin{array}{c}\text { Loading } \\
\text { Range }\end{array}$ & $\begin{array}{c}\text { Composite } \\
\text { Reliability (CR) }\end{array}$ & $\begin{array}{c}\text { Cronbach's } \\
\text { Alpha }\end{array}$ & AVE \\
\hline SD & $0.911-0.951$ & 0.95 & 0.924 & 0.865 \\
IC & $0.733-0.847$ & 0.892 & 0.848 & 0.624 \\
SN & $0.804-0.850$ & 0.894 & 0.841 & 0.677 \\
SC & $0.708-0.804$ & 0.855 & 0.774 & 0.596 \\
LS & $0.743-0.864$ & 0.94 & 0.927 & 0.662 \\
WC & $0.768-0.832$ & 0.871 & 0.803 & 0.629 \\
CS & $0.759-0.926$ & 0.917 & 0.877 & 0.734 \\
IO & $0.804-0.852$ & 0.919 & 0.89 & 0.694 \\
\hline
\end{tabular}

Note: $S D=S u f f i c i e n c y$ of Donation; IC=Intellectual Capital; $S N=S$ Chool Networking; $S C=S t u d e n t$ Competency; $L S=$ Leadership; WC=Workplace Climate; $C S=$ Citizenship; IO=Innovation

\section{Discriminant Validity}

Discriminant validity determines which construct is truly distinct from other constructs by empirical standards. The cross-loadings, Fornell-Larcker criterion, especially the heterotrait-monotrait (HTMT) ratio of correlations, can be used to examine discriminant validity. This study only used the HTMT approach for discriminant validity. As shown in Table 5, the HTMT for all constructs is below 0.90, which demonstrates adequate discriminant validity.

Table 5: The HTMT Results

\begin{tabular}{|c|c|c|c|c|c|c|c|c|c|}
\hline & Citizenship & $\begin{array}{c}\text { Sufficiency of } \\
\text { Donation }\end{array}$ & Innovation & $\begin{array}{c}\text { Intellectual } \\
\text { Capital } \\
\end{array}$ & Leadership & Reputation & $\begin{array}{c}\text { School } \\
\text { Networking } \\
\end{array}$ & $\begin{array}{c}\text { Student } \\
\text { Competency } \\
\end{array}$ & $\begin{array}{c}\text { Workplace } \\
\text { Climate } \\
\end{array}$ \\
\hline \multicolumn{10}{|c|}{ 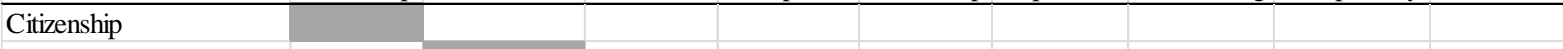 } \\
\hline Sufficiency of Donation & 0.077 & & & & & & & & \\
\hline Innovation & 0.587 & 0.072 & & & & & & & \\
\hline Intellectual Capital & 0.478 & 0.112 & 0.518 & & & & & & \\
\hline Leadership & 0.592 & 0.114 & 0.603 & 0.604 & & & & & \\
\hline Reputation & 0.771 & 0.129 & 0.818 & 0.845 & 0.9 & & & & \\
\hline School Networking & 0.511 & 0.171 & 0.374 & 0.588 & 0.553 & 0.746 & & & \\
\hline Student Competency & 0.42 & 0.079 & 0.617 & 0.738 & 0.64 & 0.853 & 0.54 & & \\
\hline Workplace Climate & 0.589 & 0.089 & 0.691 & 0.658 & 0.671 & 0.885 & 0.526 & 0.652 & \\
\hline
\end{tabular}

\section{Hypothesis Testing}

For this, the path analysis was used to test hypotheses of reputation to sufficiency of donation received generated from the research model. The $\mathrm{R}^{2}$ for dependent variable (sufficiency of donation) is 0.031 , meaning that only $3.1 \%$ of the variance can be explained by reputation. This result is considered as weak. Next, the $\mathrm{f}^{2}$ is a complementary test for $R^{2}$, where changes to $R^{2}$ are observed with the omission of any selected exogenous variable from the model. Results of $\mathrm{f}^{2}$ values show that 
INTERNATIONAL JOURNAL OF ACADEMIC RESEARCH IN BUSINESS AND SOCIAL SCIENCES Vol. 10, No. 9, 2020, E-ISSN: 2222-6990 @ 2020 HRMARS

reputation has a medium effect on sufficiency of donation. Another assessment of the structural model is predictive relevance $\left(Q^{2}\right)$, which is a measure of a model's predictive power. The indices for the value of $\mathrm{Q}^{2}$ after conducting the blindfolding analysis (as presented in Table 6 ) are above zero, therefore it shows that the structural model for this study has predictive relevance.

Table 6: Path Coefficient

\begin{tabular}{cccccccccc}
\hline Relationship & Beta & Std Error T- Value P Values & $\mathbf{R}^{\mathbf{2}}$ & $\mathbf{Q}^{\mathbf{2}}$ & $\mathbf{f}^{\mathbf{2}}$ & Decision \\
\hline Reputation -> Sufficiency of Donation & 0.158 & 0.089 & $1.7 *$ & 0.045 & 0.031 & 0.015 & 0.016 & Supported \\
\hline
\end{tabular}

\section{Conclusion}

The motivation for this study emerged from concerns regarding the financial problems faced by most private Islamic schools in Malaysia. Many private Islamic schools in Malaysia experience the problem of insufficient funds, which restrain these schools from flourishing, while retarding the progress of physical development, distract the teaching and learning process and others. Most private Islamic schools in Malaysia depend on public donations since tuition fees alone are not enough to cover the cost of operating these schools. This study is a quantitative research and it intended to measure the relationship that reputation has with the sufficiency of donation received among private Islamic schools in Malaysia. Since sufficiency of donation received is closely related to the donating behaviour of the donors, finding from this study confirm that good reputation positively and significantly affect the sufficiency of donation received. Therefore, the management of private Islamic schools should implement strategies to gain the trust of the stakeholders. Among the ways to gain the trust of donors is by strengthening the school's reputation by empowering the school's intellectual capital, improving student competency, enriching leadership, strengthening networking with stakeholders, expanding citizenship activities, improving the workplace climate and enhancing teaching innovations.

\section{Acknowledgement}

The research study is financed by Ministry of Higher Education Malaysia as well as University Malaysia Kelantan under SLAB program. The researcher also wishes to thank Dr Kati Suomi from University of Turku, Finland for sharing information regarding this subject. This acknowledgement also goes to Ustaz Abdul Rashid b Abdul Lateh, the Principal of SRI Aman Wakaf Bharu, Ustaz Ahmad Shairazi b Hj Atiqullah, the General Secretary of Pusat Pembangunan Pondok Berhad, Ustaz Usman b Alias, the Director of Pusat Pendidikan Aman, Ustaz Nik Omar b Nik Abdul Aziz, the Chairman of YADIM, Nik Mohd Azam Nik Wajis and all principals, chairmans, teachers and all the respondents and interviewees of pondok, tahfiz, SRI and SMI for their support and willingness to devote their precious time and effort to be a part of this study as well as their cooperation, valuable information and assistance in the data collection. Not to forget, to all enumerators who offered their time and effort in helping me completing the survey.

\section{Corresponding Author}

Sofri b Yahya, Graduate School of Business, Universiti Sains Malaysia, Email: sofri@usm.my 
INTERNATIONAL JOURNAL OF ACADEMIC RESEARCH IN BUSINESS AND SOCIAL SCIENCES Vol. 10, No. 9, 2020, E-ISSN: 2222-6990 @ 2020 HRMARS

\section{References}

Andres, L. (2017). History repeats itself because we fail to learn from the past. New Straits Times. Retrieved from https://www.nst.com.my/opinion/columnists/2017/09/280636/historyrepeats-itself-because-we-fail-learn-past

Aziz, M. A. F. A. (2018). Kuantan tahfiz worker to be charged with sexual abuse of 10 boys. New Straits Times. Retrieved from https://www.nst.com.my/news/crimecourts/2018/03/347636/kuantan-tahfiz-worker-be-charged-sexual-abuse-10-boys

Banding, M. P., \& Mayangsari, S. (2017). The Impact of Financial and Non-Financial Information Disclosure to Donation Decision in NonProfit Organization by Individual Donor (A TrueExperiment Research). Research Journal of Finance and Accounting.

Bernama. (2018). Two teachers detained for allegedly threatening to cut off boy's private part. New Straits Times. Retrieved from https://www.nst.com.my/news/nation/2018/09/407519/twoteachers-detained-allegedly-threatening-cut-boys-private-part

Daud, M., Umar, A., \& Maidin, M. (2012). Cabaran Pertumbuhan dan Pengelolaan Sekolah Agama Swasta di Malaysia. Prosiding Seminar Penyelidikan Pendidikan IPG. https://scholar.google.com/scholar?start=40\&q=sistem+pendidikan+British\&hl=en\&as_sdt=0, $5 \# 0$

Donkers, B., Van Diepen, M., \& Franses, P. H. (2016). Do charities get more when they ask more often? Evidence from a unique field experiment. Journal of Behavioral and Experimental Economics, 0, 1-8. https://doi.org/10.1016/j.socec.2016.05.006

Huang, S. L., \& Ku, H. H. (2016). Brand image management for nonprofit organizations: Exploring the relationships between websites, brand images and donations. Journal of Electronic Commerce Research, 17(1), 80-96.

Kashif, M., Sarifuddin, S., \& Hassan, A. (2015). Charity donation : intentions and behaviour. Marketing Intelligence \& Planning, 33(1), 90-102. https://doi.org/10.1108/MIP-07-2013-0110

Kong, E., \& Farrell, M. (2010). The Role of Image and Reputation as Intangible Resources in NonProfit Organisations: A Relationship Management Perspective. 7th International Conference on Intellectual Capital, Knowledge Management \& Organisational Learning, November.

Moraga, E. T.-, Parraga, A. Z. V.-, \& Barra, C. (2010). Antecedents of donor trust in an emerging charity sector: The role of reputation, familiarity, opportunism and communication. Transylvanian Review of Administrative Sciences, 29 E, 159-177.

Sargeant, A. (2001). Relationship fundraising How to Keep Donors Loyal. NonProfit Management \& Leadership, 12(2), 177-192. http://samples.sainsburysebooks.co.uk/9780787966812_sample_385619.pdf

Sargeant, A., \& Lee, S. (2002). Individual and contextual antecedents of donor trust in the voluntary sector. Journal of Marketing Management, 18(February), 779-802. https://doi.org/10.1362/0267257022780679

Shamsuri, N. A. (2018). Pengurusan Kewangan Sekolah Agama Persendirian (SAP): Kajian Kes Di Daerah Baling. http://ethesis.uthm.edu.my/276/1/psm.pdf

Ying, T. P. (2018). Four girls injured in Subang Jaya tahfiz school fire. New Straits Times. Retrieved from https://www.nst.com.my/news/nation/2018/04/355314/four-girls-injured-subang-jayatahfiz-school-fire 